\title{
Permanent trawl fishery closures in the Mediterranean Sea: An effective management strategy?
}

\author{
Fabio Pranovi*, Marco Anelli Monti, Alberto Caccin, Daniele Brigolin, Matteo Zucchetta \\ Environmental Sciences, Informatics and Statistics Department - CEMAS, Ca' Foscari University of Venice, via Torino 155, 30170 Venice, Italy
}

\section{A R T I C L E I N F O}

\section{Article history:}

Received 21 April 2015

Received in revised form

6 July 2015

Accepted 6 July 2015

\section{Keywords:}

Trawl fishery

Spatial closure

LPUE

Fishing effort

Fishery management

Adriatic Sea

\begin{abstract}
A B S T R A C T
Since June 2010 the Italian government prohibited the trawling activity within three nautical miles from the coast or within the $50 \mathrm{~m}$ isobath. This decision was expected to have a great impact on trawl fishing activities, but at the moment no real assessment of the effects on catches and possible ecological implications has been undertaken. In order to fill this gap, an assessment on the North Western Adriatic Sea coast has been performed. Landings per Unit of Effort (kilograms per boat per day) for each trawling fleet segment have been analysed, by comparing on a monthly basis the before (2007-2009) and after ban (2011-2013) period. The comparison was carried out considering total landings and the six main species targeted inside the three miles area (sand smelt, cuttlefish, red mullet, sole, turbot, and mantis shrimp). Within a general reduction of total landings, a differential effect based on the analysed métiers was detected, with small trawlers being more negatively affected than the large and rapido ones, which showed, for some species, positive impacts. From an ecological point of view, though, no positive overall effects were detected, probably due to the fact that the adopted measure is not sufficient to reduce the overexploitation. In any case, all this is affecting the structure of the small-scale fishery in the area, since small trawlers are changing métier, moving towards the artisanal fishery, with deep impacts on the very coastal area that the trawling ban was designated to protect, compromising all possible benefits.
\end{abstract}

(c) 2015 Elsevier Ltd. All rights reserved.

\section{Introduction}

Expanding human activities in coastal areas increasingly require management approaches capable to cope with multiple-use conflicts [8]. In order to be implemented, these approaches require integrated planning tools, such as strategic assessment, coastalzone management, and marine spatial planning for regulating, managing, and protecting the marine environment [4,9]. Within this context, an accurate assessment of the spatial distribution of human activities and associated pressures is crucial for the successful implementation of marine spatial planning [10]. Since fishing activities are recognised as one of the most important drivers affecting marine ecosystems [35], when defining marine management plans it is important to take into account the spatial extent and patchiness of such activities $[17,30]$. This plays an important role also concerning the use of fishery-closed areas as a management tool. Scientific debate about the real utility of this approach is still open, with main focus on consequences induced

\footnotetext{
* Corresponding author.

E-mail address: fpranovi@unive.it (F. Pranovi).
}

by the displacement of activities from closed areas to alternative locations $[15,29]$. This clearly contrasts with one of the key management objectives established by the European Common Fishery Policy (CFP), which consists in the reduction of fishing effort in the European Seas, also through the adoption of permanent and temporal closures [19].

At present, in Italy, fishing effort limitation (as licences, days at sea, temporal closures), technical measures (as mesh size, gear limitation), and output controls (as legal size, but not quotas) represent the principal instruments implemented to manage the fishing activities. Permanent closures, such as no taking zone, is not a common management tool. For this reason, the Council Regulation (EC) nr. 1967/2006 implementation along the Italian coasts, was expected to have a great impact. The regulation, indeed, put into force in 2010, prohibits trawling activities within three nautical miles from the coast or within the $50 \mathrm{~m}$ isobath where this is closer to the shoreline. This measure was expected to deeply affect fishing activities in the Adriatic Sea, the Northern part of which can be considered as a large trawlable area. This area was subjected for decades to a derogation from the ban (defined by the Italian legislation since 1968, art. 111 DPR nr 1639/1968), in 
relation to the exploitation of sand smelt (Atherina boyeri) during the Winter season (from November to February), and cuttlefish (Sepia officinalis) during Spring (from April to mid June). According to this, in 2010, 336 of the 712 trawl fishing licenced vessels operated in derogation to the ban [20,6]. Within the context of the Adriatic trawl fishery fleet, three segments can be recognised, in relation to the vessel length and used gear: small and large otter trawlers, and rapido trawlers (the rapido is sort of beam trawl, rigged with $10 \mathrm{~cm}$ long iron teeth, see [25]). Till a few decades ago, the division among these segments was clear, with small trawlers fishing all the year in the in-shore area, large trawlers exploring off-shore areas and rapido trawlers exploiting scallops banks in the off-shore sandy areas and flatfish along the coast, depending on the season. However, as a consequence of the depletion of resources and collapse of some stocks, (like scallops) this division progressively disappeared, with target species and fishing grounds significantly overlapping.

At the moment, no real assessment of the effects on catches and possible ecological implications has been undertaken. This paper aims to fill this gap, focusing on (i) the effects assessment on Landings per Unit of Effort ( $\mathrm{kg}_{\text {boat }}{ }^{-1} \mathrm{day}^{-1}$ ) for the different fleet segments; (ii) a preliminary analysis of potential ecological implications, by applying trophodynamic indicators. Results were discussed in the light of modifications acting on the fleet structure, and the possible consequences on the global fishing activities in the North Western Adriatic coastal area.

\section{Materials and methods}

\subsection{Study area}

Being the widest continental shelf in the Mediterranean Sea, the Northern portion of the Adriatic Sea (NAS) (Fig. 1) is characterised by relatively high productivity, which configures a unique habitat [23] in the context of the generally oligotrophic conditions of the basin. NAS is shallow ( $\max 35 \mathrm{~m}$ ), semi-enclosed, and characterised by the presence of incoherent sediments, and its high productivity is mainly associated to high nutrient loads coming from the river discharge [11]. These features render it a flat trawlable platform, concentrating more than $15 \%$ of the Italian fishing activities, and making it the most exploited Italian basin [1]. The main fishing activity is the exploitation of demersal fish and shellfish. The fleet is composed by polyvalent small-scale boats, otter trawls, rapido trawls, hydraulic dredges and mid-water trawls [31]. The port of Chioggia, located in the Southern part of the Venice lagoon (Fig. 1), hosts the most important fishing fleet in the basin, comprising $90 \%$ of the fishing vessels in the region, with all the different métiers well represented. Therefore, landings from this fleet can be considered as largely representative of the study area.

\subsection{Fleet and landing data}

By using the European fleet register (http://ec.europa.eu/fish

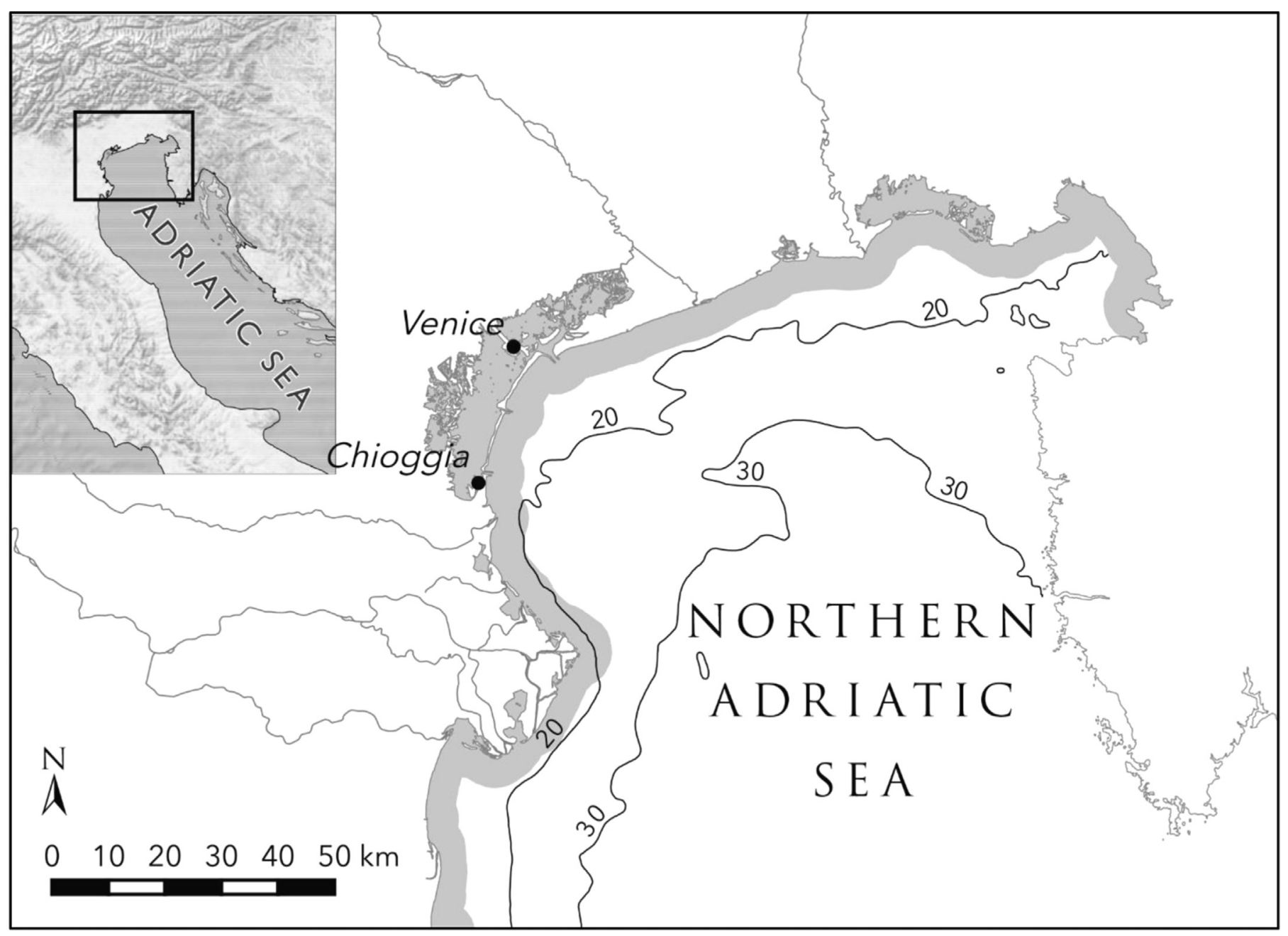

Fig. 1. The Northern Adriatic basin, showing the location of the port of Chioggia; the three miles area subjected to the trawl fishery ban is marked in grey; the 20 and $30 \mathrm{~m}$ isobaths are also reported. 
eries/fleet/index.cfm), it was possible to assign each fishing vessel in Chioggia to a specific métier. This way vessels were grouped according to their first licence (otter trawling vs. others), and sorted into two length classes, $<15 \mathrm{~m}$ (small trawlers -ST) and $>15 \mathrm{~m}$ loa (large trawlers - LT). Since rapido (R) is a fishing technique specific to the NAS, it is not distinguishable from otter trawling in terms of licence, and direct observations on the quay were necessary in order to separate them.

The landing dataset was based on the official statistics from the Chioggia fish market. Crossing quantities, days and sellers, for some vessels, belonging to the three trawl fishery segments (19 ST, 11 LT and 26 R), it was possible to estimate the Landings Per Unit of Effort (LPUE) ( $\mathrm{kg}$ boat $^{-1} \mathrm{day}^{-1}$ ). Data were then analysed by comparing the period before (Jan 2007 - Dec 2009) and after the ban (January 2011-December 2013). For each métier, the total LPUE and the LPUE of the six main species targeted by trawl fishery in the in-shore area [24] were considered. In particular, the attention has beenfocused on sand smelt ( $A$. boyeri) and cuttlefish (S. officinalis) (being these the two species for which the derogation to the ban was admitted till June 2010), red mullet (Mullus barbatus), sole (Solea vulgaris), turbot (Scophthalmus rhombus and S. maximus) and mantis shrimp (Squilla mantis), which globally account for about $50 \%$ of total landings at the Chioggia fish market. The complete list of species targeted by each métier is reported in the Table S1.

\subsection{Statistical analysis}

In order to explore the effects of the ban on the métiers considered in this study, a model-based inference (sensu [2]) was carried out. Three alternative different model formulations were defined, representing different a priori hypotheses on the type of influence of the ban on landings. The most adequate response was determined on the basis of Akaike Information Criteria (AIC).

Generalized Additive Models (GAM) [34,36] were used to describe the total landings and LPUE of the different segments of trawl fishing (ST, $L T$ and $R$ ) in relation to the main target species and to compare the two time periods (before and after the ban). Data were preliminarily transformed $(\log +1)$ in order to minimise the variance heterogeneity. The models were fitted using the $m g c v$ package [34] in R ( $R$ Development Team 2014 version 3.0.2). The distribution family was always assumed Gaussian with an identity link function, and the class of the smoother was a cyclic penalised cubic regression spline. The explanatory variables considered in the analyses were months, the factor 'period' (before or after the ban), interactions between the smoother of month and the factor period.

The first model (Type A) hypothesises a dependence of landings (or LPUE) from the month (MO) alone (Eq. (1)). In this case, the $B A$ (before/after) factor is absent (i.e. the effect of the ban is assumed not-relevant).

$\log \left(\right.$ Landings $\left._{i}\right)=\alpha+f\left(M O_{i}\right)+\varepsilon_{i}$

where $\alpha$ is the intercept, $f$ is the smoothing function, and $\varepsilon$ is a normally distributed noise with expectation 0 and variance $\delta^{2}$.

The second model (Eq. (2); Type B) relates the landings to the month $(M O)$ as a smoother plus a before/after factor $(B A)$ that acts only on the magnitude of the response. This model is based on the hypothesis that the landings time-trend is governed by seasonal drivers, while the effect of the ban is limited to shifting the average value of the landings (i.e. the ban leads to an increase or decrease in the magnitude of the catches, without affecting the temporal pattern).

$\log \left(\right.$ Landings $\left._{i}\right)=\alpha+f\left(M O_{i}\right)+\operatorname{factor}\left(B A_{i}\right)+\varepsilon_{i}$
The last model (Eq. (3); Type C) describes the time-trend of the landings via a monthly smoother as the driver variable for a before/after factor that could affect the form of the trends in the two periods (interaction between $M O$ and $B A$ ). This represents the strongest possible effect of the ban, in that the seasonal pattern of landings changes after the ban.

$\log \left(\right.$ Landings $\left._{i}\right)=\alpha+f\left(M O_{i}\right):$ factor $\left(B A_{i}\right)+\varepsilon_{i}$

Interactions between $\mathrm{MO}$ (monthly smoother) and BA (categorical variable) was fitted using the 'by' command in the $m g c v$ package. It applies a monthly smoother to the data for each period. In this case $B A$ factor has a role as a possible modifier of the trend's intercept.

\subsection{Ecological indicators}

To investigate possible ecological implications related to the quantity and quality changes in trawl fishery landings, trophodynamic indicators have been applied to the time series (2007-2013) of annual data, based on the list of targeted species (Table S1). For each species the trophic level (TL) was assigned according to [26] (Table S1).

As proposed by [27], the analysis of biomass accumulation across the trophic levels (CumB vs TLs) represents a promising indicator to detect modifications at the highest hierarchical levels. The method is based on the observation that, in marine ecosystems, the CumB vs TLs curve displays a sigmoidal pattern, with a biomass accumulation at the intermediate TLs (around 3.2-3.5). By analysing the main parameters describing the curve shape, as the inflection point and the steepness of the tangent to the inflection point, it is thus possible to compare different ecological conditions, assuming that a reduction of the steepness accompanied by an increase of the inflection point TL indicates a general decrease of conditions $[26,27]$.

The Primary Production Required to sustain fishery is a measure of the level of exploitation of the studied area [22], accounting for the fraction of Primary Production sequestrated by fisheries. The method is based on the trophic level of the caught species, the energy transfer efficiency between trophic levels, and on the primary productivity of the basin, combined as follow:

$P P R=\sum_{i=1}^{n} \frac{L_{i}}{C R}\left(\frac{1}{T E}\right)^{\left(T L_{i}-1\right)}$

with $L_{i}=$ landing of the $i$-species;

$C R=$ conversion rate of wet weight to carbon (fixed at 1:9, according to [22])

$T E=$ transfer efficiency (fixed at $10.5 \%$, according to [5]);

$T L=$ trophic level of $i$-species.

The PPR is commonly expressed as a percentage of the total primary production. Primary production for the NAS was estimated by using monthly chlorophyll-a data derived from MODIS satellite (http://neo.sci.gsfc.nasa.gov/), according to [3] (see Supplementary Material)

\section{Results}

\subsection{Fishing capacity trends}

Data about the trawl fishing fleet for the 2007-2013 period showed a decreasing trend in the number of vessels, in both the analysed segments ( $<15 \mathrm{~m}$ and $>15 \mathrm{~m}$ loa). On the contrary, the gross tonnage (GT) and power (HP) per boat increased, with the exception of the GT per boat in the $<15 \mathrm{~m}$ segment (Fig. 2). The 
combined picture suggests a change in the fleet structure towards less fishing vessels, larger and more powerful.

\subsection{Trends of total landings}

Total LPUE showed a strong seasonality in all the considered cases, characterised by a minimum at the end of Spring-Summer and a peak in Fall, with a shift in timing depending on the fishing technique (Fig. 3). The before/after (BA) comparison showed a significant reduction of landings in the after-ban period (Fig. 3). The shape of the trend remained the same in both periods, for all métiers (Model Type B, Table 1), with the exception of small trawlers, which showed a significant seasonal shift (Model Type C, Table 1). The reduction appeared more pronounced at the métiers level than on the total landings (Fig. 3).

\subsection{Target species analysis}

On the basis of the LPUE data, the six selected species account on average for about $50 \%$ of the total value, representing $50 \%$ in the ST, $30 \%$ in the LT and $71 \%$ in the R. The BA comparison can be summarised as follows:

Cuttlefish (S. officinalis) - A significant decrease in terms of total landings (model Type B, Table 1), was detected. The BA factor plays an important role in determining a seasonal shift in LPUE for both $S T$ and $R$ (Type C, Table 1 ), whereas a significant reduction was detected for $L T$ (Type B, Table 1) (Fig. 4).

Mantis shrimp (S. mantis) - A significant reduction after the ban (Type B, Table 1) was detected in the total landings and in the $S T$ and $L T$ LPUE, whereas no significant effect was recorded for the
$R$ LPUE (Type A, Table 1) (Fig. 4).

Red mullet ( $M$. barbatus) - The $B A$ factor was found significant for total landings, with a change in the seasonality as in the case of $R$ and an increase of LPUE for LT (Type C, Type B, respectively; Table 1); no significant effects were detected for ST (Type A, Table 1) (Fig. 4).

Sand smelt ( $A$. boyeri) - No differences in the $B A$ comparison were detected (model Type A, Table 1 ), both for total landings and LPUE for the small trawlers (ST) (Fig. 4). In the case of LPUE the strong seasonality is quite evident, since this species is present at sea only during the winter season (Fig. 4). The species is not targeted by the other two trawling fleet segments, large trawlers $(L T)$ and rapido $(R)$.

Sole (S. solea) - The BA factor plays no significant role for total landings (Type A, Table 1); conversely, it proved important in determining changes of LPUE in all the three segments, albeit with opposite trends (decreasing in $S T$, increasing in $L T$ and $R$ ) (Type B, Table 1) (Fig. 4).

Turbot (S. rhombus and S. maximus) - A significant effect of the BA factor was detected in terms of an increase in total landings (Type B, Table 1) and a shift of seasonality for the ST LPUE (Type C, Table 1); no significant effects were recorded for $L T$ and $R$ (Type A, Table 1) (Fig. 4).

\subsection{Ecological implications}

The trophodynamic indicators confirmed the presence of changes across the time series. The analysis of the biomass accumulation across TLs showed, indeed, modifications in the curve shape, resulting in an increase of the inflection point $(T L)$ and a
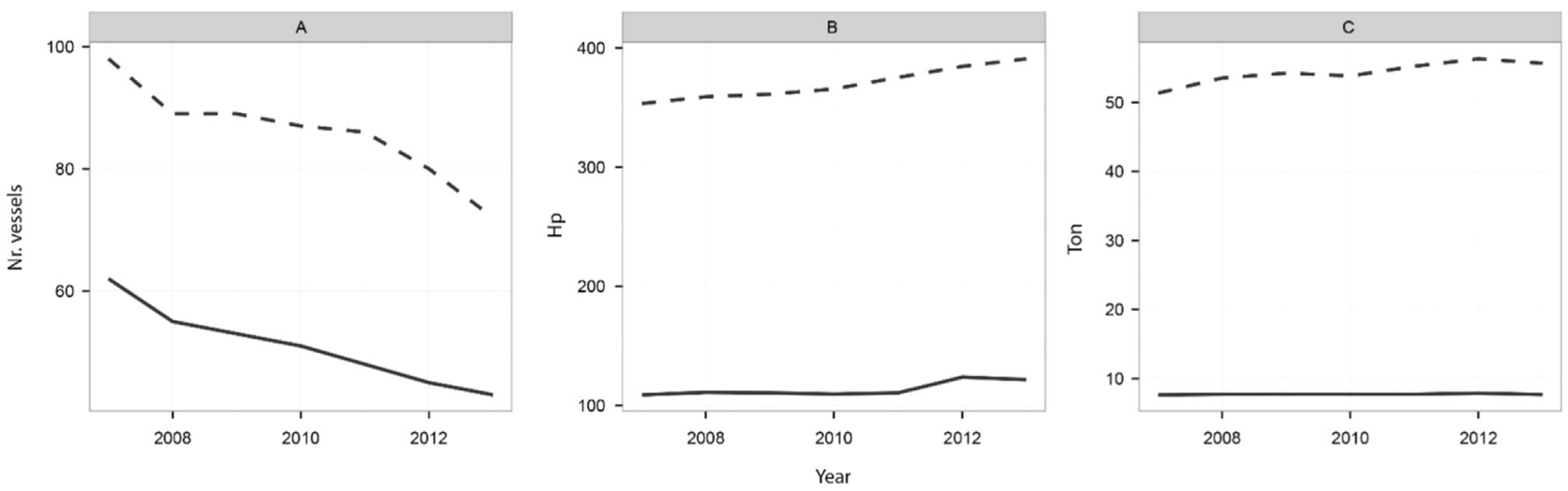

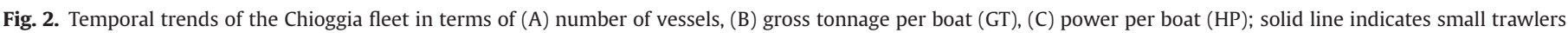
$(<15 \mathrm{~m})$, dashed line indicates the large ones $(>15 \mathrm{~m})$.
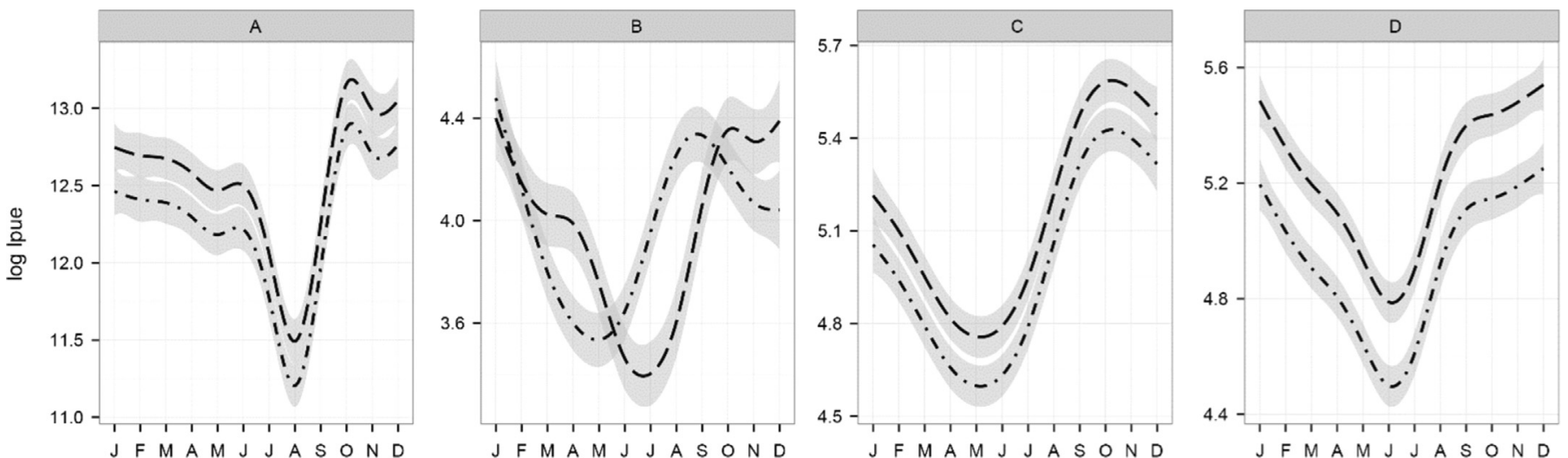

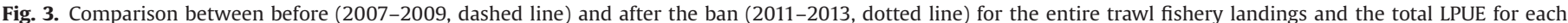
trawling fleet segments; (A) entire fleet, (B) small trawlers, (C) large trawlers and (D) rapido trawlers. 
Table 1

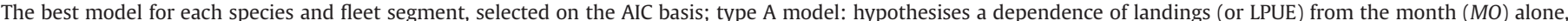

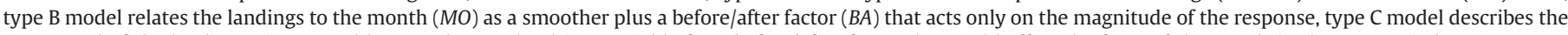
time-trend of the landings via a monthly smoother as the driver variable for a before/after factor that could affect the form of the trends in the two periods.

\begin{tabular}{|c|c|c|c|c|}
\hline Species & Fleet segment & $\begin{array}{l}\text { Model type A } \\
\text { MO alone }\end{array}$ & $\begin{array}{l}\text { Model type } \mathrm{B} \\
\text { BA effect on the trend magnitude }\end{array}$ & $\begin{array}{l}\text { Model type } C \\
\text { BA effect on the trend shape }\end{array}$ \\
\hline \multirow[t]{4}{*}{ All } & Entire fleet & & Before $>$ After & \\
\hline & Small trawlers & & & Complex pattern \\
\hline & Large trawlers & & Before $>$ After & \\
\hline & Rapido & & Before $>$ After & \\
\hline \multirow[t]{4}{*}{ Cuttlefish } & Entire fleet & & Before $>$ After & \\
\hline & Small trawlers & & & Complex pattern \\
\hline & Large trawlers & & Before $>$ After & \\
\hline & Rapido & & & Complex pattern \\
\hline \multirow[t]{4}{*}{ Mantis shrimp } & Entire fleet & & Before $>$ After & \\
\hline & Small trawlers & & Before $>$ After & \\
\hline & Large trawlers & & Before $<$ After & \\
\hline & Rapido & $v$ & & \\
\hline \multirow[t]{4}{*}{ Red mullet } & Entire fleet & & & Complex pattern \\
\hline & Small trawlers & $v$ & & \\
\hline & Large trawlers & & Before $<$ After & \\
\hline & Rapido & & & Complex pattern \\
\hline \multirow[t]{2}{*}{ Sand smelt } & Entire fleet & $\nu$ & & \\
\hline & Small trawlers & $v$ & & \\
\hline \multirow[t]{4}{*}{ Sole } & Entire fleet & & Before $<$ After & \\
\hline & Small trawlers & & Before $<$ After & \\
\hline & Large trawlers & $\mathrm{v}$ & & \\
\hline & Rapido & & Before $>$ After & \\
\hline \multirow[t]{4}{*}{ Turbot } & Entire fleet & v & & \\
\hline & Small trawlers & $\nu$ & & \\
\hline & Large trawlers & & Before $<$ After & \\
\hline & Rapido & & & Complex pattern \\
\hline
\end{tabular}

reduction of the steepness, after 2010 (Fig. 5). This can be interpreted as a 'stretching' of the curve, due to a reduction of accumulation at the intermediate TLs. These results are in agreement with the \%PPR, showing no clear effects of the ban, with a reduction till 2010 followed by a partial increase of the values (Fig. 6) as confirmed by the $\mathrm{B} / \mathrm{A}$ comparison with no significant variations of the values.

\section{Discussion}

At present, in Italy no fishing activity is subjected to quotas (with the exception of the bivalves exploitation). The management regime for trawling only defines the effort limits, in terms of number of days at sea (4 per week); moreover, a temporary fishing closure (45 days) is enforced during Summer (usually between July and August). For a period of 10 weeks after the temporary closure, trawling is restricted to 3 days per week. Before 2010, however, the effort regime was less strict, allowing to fish from Monday to Friday (reduced to 4 days in the 10 weeks immediately after the temporary closure).

As it is now four years the trawl fishery ban within the three miles area (Council Regulation nr. 1967/2006) was put into force along the Italian coasts, it is time to assess its effects on the different métiers and its possible ecological implications. In particular, the measure was expected to have a great impact on the fishing activities in the Adriatic Sea, in relation to the derogations allowing the trawl fishing in the coastal area for exploiting sand smelt (A. boyeri) and cuttlefish (S. officinalis), during the Winter and Spring season, respectively. But results seem delineate a different picture. In general terms, the recorded annual LPUE (average value before the ban) revealed a marked difference between the small trawlers $\left(62 \mathrm{~kg} \mathrm{v}^{-1} \mathrm{~d}^{-1}\right.$ ), and the other two métiers (189 and $195 \mathrm{~kg} \mathrm{v}^{-1} \mathrm{~d}^{-1}$, for LT and $\mathrm{R}$ respectively), suggesting a higher vulnerability of this fleet segment to possible changes. These values are also lower than those reported, at the regional level, for the trawl fishery in $2000\left(214 \mathrm{~kg} \mathrm{v}^{-1} \mathrm{~d}^{-1}\right)$ [6], confirming a decreasing landings trend also for this basin [7].

As a consequence of the ban, the ST showed a significant change in seasonality, whereas LT and R showed a significant total LPUE reduction; this reflected also at the level of the entire fleet landings, even if less evidently. These results suggested the presence of differential effects related to the different métiers, confirmed by the analysis at the single target species level:

- small trawlers were the most impacted by the ban, with a LPUE reduction recorded for two of the main target species and stable values for the others;

- the other two métiers enjoyed some advantages, more evident for large trawlers (sole and red mullet increased LPUE), that revealed to be the segment better able to exploit new conditions.

Red mullet, sole and turbot, are the species which clearly differentiate the métiers; the ST showed a reduction (sole and turbot) or a stable pattern (red mullet), whereas at least one (red mullet and turbot) or both LT and R (sole) showed an increase of LPUE values after the ban introduction. Finally, also the stable pattern recorded for the rapido mantis shrimp LPUE can be interpreted as a positive effect, since this species showed significant decreases in terms of total landings and a declining trend has been reported by stock assessment results in the area (Giovanardi pers. comm.).

The case of the sand smelt is particularly interesting, within a context of the ban implementation. It was expected that the permanent closure of the coastal area to trawl fishery would produce the complete disappearance of landings during the Winter season [6]. On the North Western coast of the Adriatic Sea, indeed, this species is present at sea only in late Fall and Winter, migrating inside coastal lagoons during the rest of the year. The fishing adapted to this behaviour, with small trawlers exploiting the resource in the inshore area during cold months and artisanal fishery targeting it in the lagoons [24]. Results, however, totally contrasted with the expectations, showing no significant reduction in the LPUE values. The would be explained with the hypothesis that small boats ( $<15 \mathrm{~m}$, not detected by the VMS system) possibly 

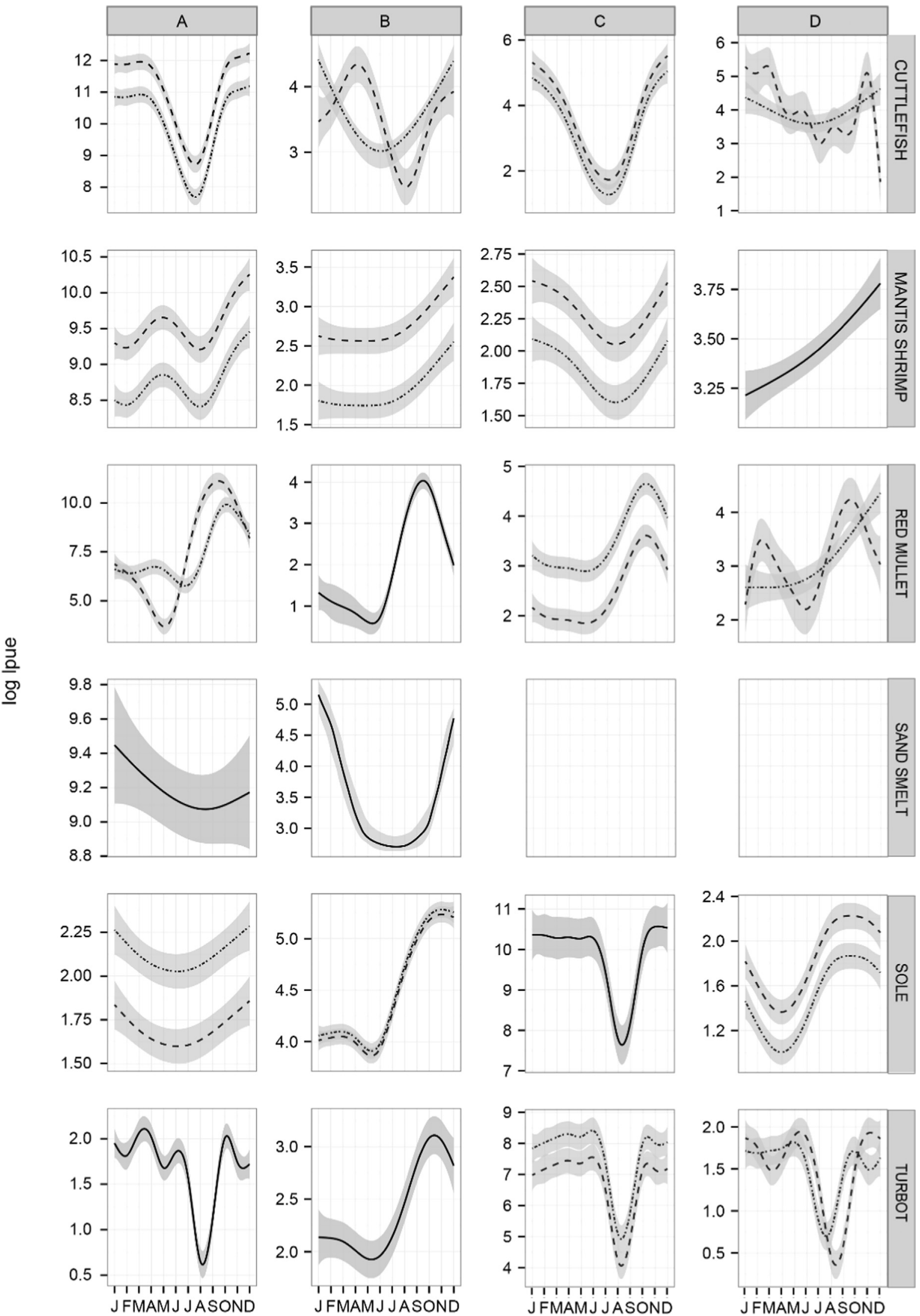

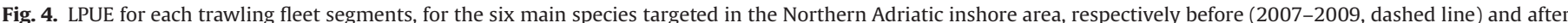
(2011-2013, dotted line) the ban; (A) entire fleet, (B) small trawlers, (C) large trawlers and (D) rapido trawlers. 

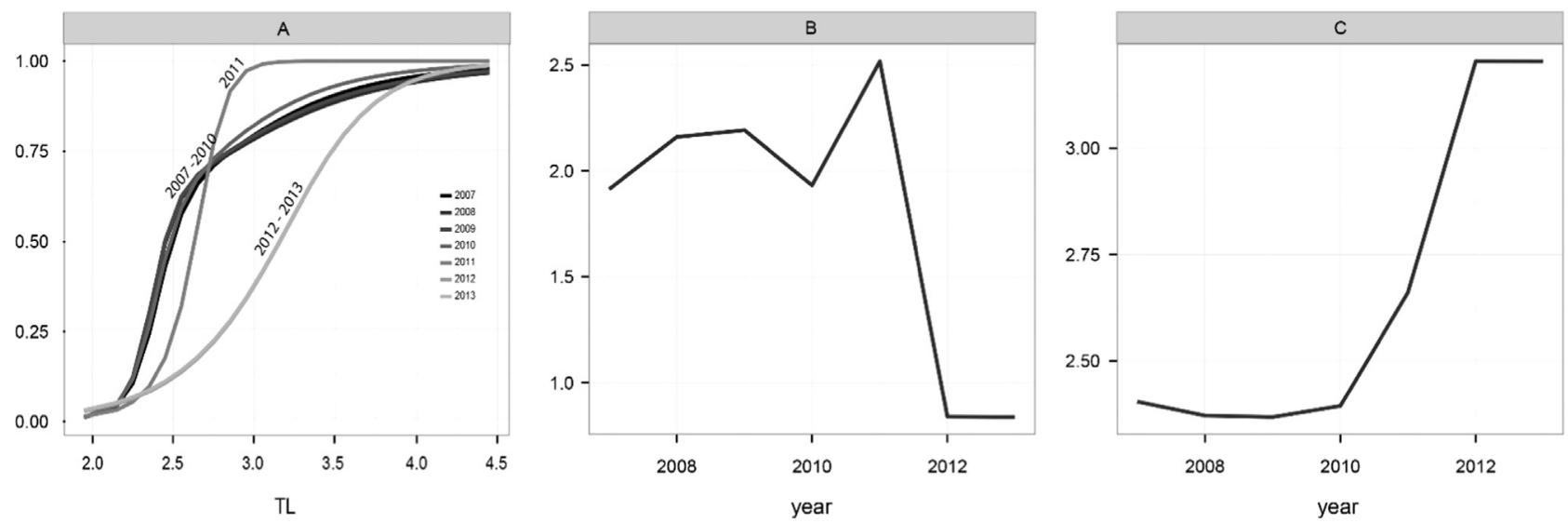

Fig. 5. Cumulative biomass across trophic levels curves; (A) annual curves, (B) inflection point and (C) steepness.

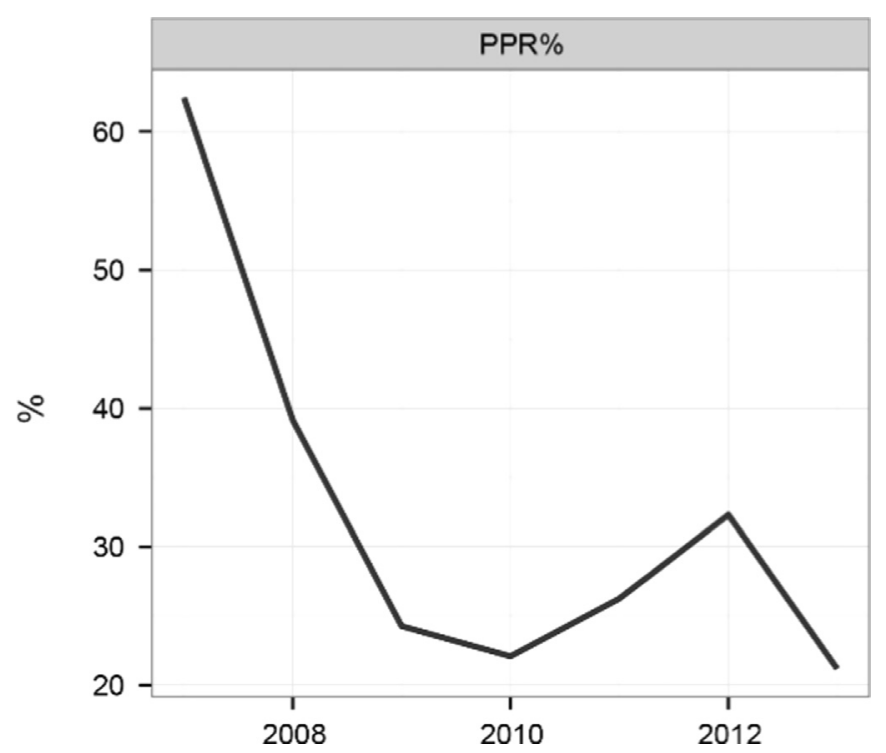

Fig. 6. Time series of the Primary Production Required to sustain catches, expressed as percentage of the Primary Production.

still fish for sand smelt inside the forbidden area during Winter. All this needs to be further analysed, and if confirmed the ban enforcement accordingly revised.

Concerning the possible ecological implications of the ban, the application of trophodynamic indicators highlighted the presence of detectable changes, with modifications of the temporal trends, even if they are still not large enough to significantly reduce the pressure on the marine ecosystem. On the contrary some evidences suggested the risk for further degradation.

According to [16], ecosystem biomass is a conservative property, which in marine environments exhibits an accumulation at intermediate TLs [18]. Changes to this accumulation have been suggested to reflect shifts in ecosystem structure [32]. Applying the CumB vs. TL method to trawling fleet landings revealed a significant stretching of the curve in 2012 and 2013 (resulting in an increase of inflection point and reduction of the steepness). This pattern, according to [27], can be interpreted as a sign of deterioration of the ecological conditions.

The Primary Production Required to sustain catches can be defined as a measure of the "appropriated carrying capacity" (sensu [28]) of ecosystems, i.e. the amount of the available energy in an ecosystem directly extracted by fishery. The values estimated by the trawling activities in the NAS ranged between 20 and 60\%, which are typical of highly exploited basins all around the world [33].
Both applied indicators highlighted the presence of a change in 2010, but none of them suggested an improvement of the ecological conditions. All this could be related to the high level of pressure at which the basin is subjected (confirmed by the high PPR values), and to the scarce effects of the ban at global level. This is in contrast with [12], which reported positive effects related to the implementation of permanent closures in the Northern-Central Adriatic Sea, simulated by a spatial model. This would be related to the fact that in real situations, no-take zones can produce a rearrangement of the fishing effort distribution reflecting in a very low reduction of the impact at regional scale [21].

One of the expected major consequences of the ban was indeed the redistribution of the trawl fishing effort, which would concentrate in the 3-6 miles area. Based on recent fishermen interviews, it was proved that, after the ban, trawlers concentrated their activity in this area, particularly in late summer and early fall, to exploit the presence of young specimens just recruited to fishery $[13,14]$.

All this, as described also for other different geographical contexts, such as the North Sea [15,29], is producing dramatic changes in the structure of the fleet along the West Northern Adriatic coast. Many fishermen, indeed, exploiting their double licences, are shifting from small otter trawling to artisanal fishing, so coming back to fish inside the three miles area. This is expected to produce an increase of the fishing effort related to the use of fixed gears inside this area, completely nullifying the reduction of fishing pressure produced by the trawling ban, also in relation to the absence of effort regulation of this fleet segment, since the fishermen are allowed to fish each day of the week, with no exclusion.

\section{Conclusions}

The present study highlighted the importance of monitoring the results of any management strategy after its implementation, in order to verify the accomplishment of the objectives and to address possible distortions. Results underline the need to elaborate new strategies in order to cope with induced fleet modifications.

In conclusion, the main results can be summarized as follow:

- The ban is possibly ineffective at reducing the fishing pressures on demersal resources, since despite a decrease for the trawl fishery, some species showed an increase of LPUE al the level of single métier.

- Artisanal fishery within the three miles area needs to be carefully managed, in order to reduce the risk that an increase of the fishing effort on this activity would compromise the possible local benefits of the ban; 
- Small trawlers represent the fleet segment more negatively affected by the ban.

A possible solution could be the integration of the small scale fishery with other activities more related with tourism, such as the development of the marine fishing tourism, in order to differentiate income sources, thus reducing the fishing pressure in the coastal area. Another opportunity could be to implement a sort of stratification of different trawling fleet segments, with a complete ban of trawling within the 3 miles area, small trawlers confined in the 3-6 miles area, and finally the big trawlers/rapido exploiting resources beyond the 6 miles. This would reduce the 'pressure' on the small trawlers segment, allowing to limit the migration of these fishermen towards other métiers, namely the artisanal activities.

\section{Appendix A. Supplementary material}

Supplementary data associated with this article can be found in the online version at http://dx.doi.org/10.1016/j.marpol.2015.07.003.

\section{References}

[1] G. Bombace, Riflessioni sulla pesca, biodiversità ed aree marine protette, Biolo. Mar. Mediterr. 9 (2002) 48-70.

[2] K.P. Burnham, D.R. Anderson, Model selection and multimodel inference: a practical information-theoretic approach, 2nd ed., Springer, New York, 2002.

[3] M.J. Behrenfeld, P.G. Falkowski, Photosynthetic rates derived from satellitebased chlorophyll concentration, Limnol. Oceanogr. 42 (1) (1997) 1-20.

[4] S.J. Boyes, M. Elliott, S.M. Thomson, S. Atkins, P. Gilliland, A proposed multipleuse zoning scheme for the Irish Sea. An interpretation of current legislation through the use of GIS-based zoning approaches and effectiveness for the protection of nature conservation interests, Mar. Policy 31 (2007) 287-298.

[5] A. Caccin, Effects of climate changes on the mediterranean nektonic communities, and consequences on commercial fisheries (Ph.D. thesis), Ca' Foscari University of Venice, Venice, 2015, p. 147.

[6] CLES, La pesca a strascico nell'alto Adriatico: crisi economica e prospettive, Cles srl, Roma (2010), p. 30.

[7] F. Colloca, M. Cardinale, F. Maynou, M. Giannoulaki, G. Scarcella, K. Jenko, J. M. Bellido, F. Fiorentino, Rebuilding Mediterranean fisheries: a new paradigm for ecological sustainability, Fish Fish. (2011) 1-21.

[8] F. Douvere, C.N. Ehler, International Workshop on Marine Spatial Planning UNESCO, Paris, 8-10 November 2006. A summary, Mar. Policy, 31, (2007) 582-583.

[9] F. Douvere, F. Maes, A. Vanhulle, J. Schrijvers, The role of marine spatial planning in sea use management: the Belgian case, Mar Policy 31 (2007) $182-191$.

[10] P.D. Eastwood, C.M. Mills, J.N. Aldridge, C.A. Houghton, S.I. Rogers, Human activities in UK offshore waters: an assessment of direct, physical pressure on the seabed, ICES Journal of Marine Science 64 (2007) 453-463.

[11] S. Fonda Umani, P. Franco, E. Ghirardelli, A. Malej, Outline of oceanography and the plankton of the Adriatic Sea, in: G. Colombo, I. Ferrari, V.U. Ceccherelli, R. Rossi (Eds.), Marine Eutrophication and Population Dynamics, Olsen \& Olsen, Fredensborg, 1992, pp. 347-365.

[12] N. Fouzai, M. Coll, I. Palomera, A. Santojanni, E. Arneri, V. Christensen, Fishing management scenarios to rebuild exploited resources and ecosystems of the Northern-Central Adriatic (Mediterranean Sea), J. Mar. Syst. 102-104 (2012) 39-51.

[13] C. Froglia, O. Giovanardi, C. Piccinetti, Valutazione dell'impatto sulle risorse biologiche della pesca a strascico entro le tre miglia, Biol. Mar. Mediterr. 7 (4) (2000) 106-111.
[14] O. Giovanardi, F. Pranovi, Analisi della pesca a strascico entro le tre miglia dalla costa nel compartimento marittimo di Chioggia, Biol. Mar. Mediterr. 5 (3) (1998) 629-637.

[15] S.P.R. Greenstreet, H.M. Fraser, G.J. Piet, Using MPAs to address regional-scale ecological objectives in the North Sea: modelling the effects of fishing effort displacement, ICES J. Mar. Sci. 66 (2009) 90-100.

[16] C.S. Holling, D.W. Schindler, B.W. Walker, J. Roughgarden, Biodiversity in the functioning of ecosystems: an ecological synthesis, in: C.A. Perrings, K. G. Maler, C. Folke, C.S. Holling, B.O. Jansson (Eds.), Biodiversity Loss, Ecological and Economical Issues, Cambridge University Press, Cambridge, 1995, pp. 44-83.

[17] S. Jennings, J. Lee, J.G. Hiddink, Assessing fishery footprints and the trade-offs between landings value, habitat sensitivity, and fishing impacts to inform marine spatial planning and an ecosystem approach, ICES J. Mar. Sci. 69 (2012) 1053-1063.

[18] J.S. Link, F. Pranovi, M. Coll, S. Libralato, V. Christensen, C. Legault, Exploring novel metrics of ecosystem overfishing using energy budget model outputs, Fish Cent. Res. Rep. 17 (2009) 153.

[19] I. Lutchman, C. Grieve, S. Des Clers, E. De Santo, Towards a reform of the Common Fisheries Policy in 2012, A CFP Health Check, IEEP, London, 2009, p. 80.

[20] MIPAAF. Nota mensile 2011 Ministero Politiche Agricole, Alimentari e Forestali, Roma, 2011, p. 12.

[21] M.A. Pastoors, A.D. Rijnsdorp, F.A. Van Beek, Effects of a partially closed area in the North Sea ("plaice box") on stock development of plaice, ICES J. Mar. Sci. 57 (2000) 1014-1022.

[22] D. Pauly, V. Christensen, Primary Production required to sustain global fisherie, Nature 374 (1995) 255-257.

[23] N. Pinardi, E. Arneri, A. Crise, M. Ravaioli, M. Zavatarelli, The physical, sedimentary and ecological structure and variability of shelf areas in the Mediterranean Sea, in: A.R. Robinson, K. Brink (Eds.), The Sea, the Global Coastal Ocean Interdisciplinary Regional Studies and Syntheses, vol. 14B, Harvard University Press, Cambridge, USA, 2006.

[24] F. Pranovi, O. Giovanardi, R. Strada, Osservazioni preliminari sulla pesca a strascico entro le tre miglia dalla costa nel Compartimento Marittimo di Chioggia, Biol. Mar. Mediterr. 3 (1) (1996) 214-221.

[25] F. Pranovi, S. Raicevich, G. Franceschini, M.G. Farrace, O. Giovanardi, "Rapido" trawling in the Northern Adriatic Sea: effects on benthic communities in an experimental area, ICES J. Mar. Sci. 57 (2000) 517-524.

[26] F. Pranovi, J. Link, C. Fu, A. Cook, H. Hui Liu, S. Gaichas, K. Friedland, K.R. Utne, $\mathrm{H}$. Benoit, Trophic level determinants of biomass accumulation in marine ecosystems, Mar. Ecol. Prog. Ser. 459 (2012) 185-201.

[27] F. Pranovi, S. Libralato, M. Zucchetta, J.S. Link, Biomass accumulation across trophic level: analysis of landings for the Mediterranean Sea, Mar. Ecol. Prog. Ser. 512 (2014) 201-216.

[28] W.E. Rees, Revisiting carrying capacity: area-based indicators of sustainability, Popul. Environ. 17 (3) (1996) 195-215.

[29] A.D. Rijnsdorp, G.J. Piet, J.J. Poos, Effort allocation of the Dutch beam trawl fleet in response to a temporarily closed area in the North Sea, ICES CM 2001/N 200101

[30] V. Stelzenmúller, S.I. Rogers, C.M. Mills, Spatio-temporal patterns of fishing pressure on UK marine landscapes, and their implications for spatial planning and management, ICES J. Mar. Sci. 65 (2008) 1081-1091.

[31] UNEP-MAP-RAC/SPA, Status and conservation of fisheries in the Adriatic Sea. in: H. Farrugio, Alen Soldo, Draft Internal Report for the Purposes of the Mediterranean Regional Workshop to Facilitate the Description of Ecologically or Biologically Significant Marine Areas, Malaga, Spain, 7-11 April, 2014.

[32] A. Sosa-López, D. Mouillot, T.D. Chi, J. Ramos-Miranda, Ecological indicators based on fish biomass distribution along trophic levels: an application to the Terminos coastal lagoon, Mexico, ICES J. Mar. Sci. 62 (2005) 453-458.

[33] R. Watson, D. Zeller, D. Pauly, Primary productivity demands of global fishing fleets, Fish Fish. 1 (5) (2014) 231-241.

[34] S.N. Wood, Generalized additive models: an introduction with R, Texts in Statistical Science, Chapman \& Hall/CRC, Boca Raton, FL, 2006.

[35] B. Worm, T.A. Branch, The future of fish, Trends Ecol Evolut. 27 (2012) $594-599$.

[36] A.F. Zuur, E.N. Ieno, G.M. Smith, Analysing ecological data, Statistics for Biology and Health, Springer, Heidelberg, Germany, 2007. 